\title{
Electronic Payment Systems (EPS) and Service Delivery in Selected Money Deposit Banks in Nigeria
}

\author{
Olajide Olubayo THOMAS ${ }^{\star}$, Jegede Charles AYODELE ${ }^{\star \star}$, Lawal Oloyede RAHEEM ${ }^{\star \star \star}$
}

\begin{tabular}{l}
\hline \multicolumn{1}{c}{ A R T I C L E I N F O } \\
\hline Article history: \\
Accepted June 2019 \\
Available online July 2019 \\
\hline JEL Classification \\
G20, G21 \\
Keywords: \\
Automated Teller Machine, \\
Electronic payment systems, \\
Money Deposit Bank, Point-of-Sale, \\
Service delivery
\end{tabular}

Introduction

Bank services over the years have undergone a kind of evolution. It has changed in terms of instruments and breadth of operation. According to Okeke, Nwatu and Ezeh (2017) these changes have been occasioned by continuous financial sector reforms and policy in the environment. The Central Bank of Nigeria (CBN) reform on payment system is designed to ensure that a large proportion of currency in circulation is captured. Over the years, what the CBN is targeting is a more or less cashless economy (Okeke et al, 2017). The introduction of technology based payment system is done to increase the convenience of customers, relief staff stress as well as making the society a cashless economy (Kelvin, 2012). Tijani and Ilugbemi (2015), posited that paying and receiving money between buyers and sellers are not necessarily to be done through raw cash exchange but can be made using electronic payment system (EPS) such as Point-of-sale (POS), Automated teller machine (ATM), terminal, Online web portal, Mobile money solutions and many others.

In Nigeria, electronic banking reformation was geared towards reducing the number of banks in the country and making the emerging banks much stronger and reliable (Soludo, 2007). The banking sector reform that compelled increase capitalisation on deposits money banks in Nigeria resulted in consolidation of banks since 2005. This has made the post consolidated banks strived for improved customer service delivery through technology adoption strategy. The attempt for improved customer's service delivery by banks could be traced to increasing demand for better services by the customers who would like to transact their banking transaction at any time and at a convenient location (Oladejo, 2016).

Bank service delivery is the focal point of customer's satisfaction and has not been fully enhanced. This is because bank workers are seriously under pressure attending to very long queue. Customers have to spend a whole day to transact business in the bank. This informed several reforms in the banking industry. In fact, the financial sector felt the banking industries are not performing as expected and unable to compete globally due to the poor capital base. This resulted in bank reforms that reduced the number of banks in Nigeria to twenty-three (23) banks in 2005 and later to nineteen (19) recently (CBN bulletin, 2017). The reform also ushered payment system, records keeping, and many others related bank transaction activities that embraced Information and Communication Technology. This is expected to bring an improvement in service delivery. Opinions differ as to whether this electronic payment system has brought relieve in 
customers' hardship or not. While some school of thought felt the hardship has been completely eliminated (Idris, Olumoko \& Ajemunigbohun, 2013; Jean 2018; Oladejo 2016 \& Shagari \& Olusegun 2014). Others believe that much has not been achieved in term of good service delivery (Okeke, Nwatu \& Eze 2017 \& Okoro 2014). It is on this note of inconclusive findings that geared the study to investigate electronic payment systems vis-a-vis customer service delivery.

\section{Statement of the Problem}

Nations across the world have witnessed success stories as a result of using improved technology for banking services, such technologies like Local Area Network (LAN), Wider Area Network (WAN), Credit Cards, Electronic Point-of-Sales (POS) system, Automated Teller Machine (ATM), and online web portal. Also, the information filling system, integrated banking system and client information filling (CIF) systems are now electronically done and being routinely used by many banks to ensure efficient and effective operations (Okoro, 2014). E-payment instrument is being noted as vital part that give rise to availability of a guaranteed and trusted e-payment system (Sumanjeet, 2009: Baddedley, 2004).

Many researchers (such as Roy \& Sinha, 2014; Hassan, Mamman \& Farouk, 2013; Joseph \& Richard, 2015; Manocharan, 2007 and Kabir, Saidin \& Ahmi, 2015) gave resultant effects of e-payment instruments on customer service delivery. The outcomes of their study have shown positive effects between electronic payment systems and service delivery in banking industry (Abubakar, Shagari \& Olusegun, 2015; Jean, 2018; Tennyson \& Mercy, 2014; Oladejo 2016 and Tijani \& Ilugbemi, 2015), others have given a negative reports (Okeke, Nwatu \& Eze, 2017 ; Okoro, 2014 ). The findings seem inconclusive, hence, this study tends to empirically investigate these two electronic banking instruments which are Automated Teller Machines (ATM) and Point of Sales (POS) terminal usage in the Nigerian business context. The applications of these two instruments over the years have been given mixed outcome among both the customers and even the bank officials in Nigeria.

\section{Objectives of the Study}

The specific objectives of the study are to:

i. examine the significant influence of the use of Automated Teller Machine (ATM) on service delivery of Money Deposit Financial Institutions.

ii. evaluate if Point-of-Sale (POS) terminal has improved service delivery of Money Deposit Financial Institutions.

\section{Research Questions}

In an attempt to achieve the set objectives in the study, the following research questions were formulated.

i. What is the influence of Automated Teller Machine usage on service delivery of Money Deposit Financial Institutions in Nigeria?

ii. How has Point-Of-Sale terminal usage improve service delivery of Money Deposit Financial Institutions in Nigeria?

\section{Research Hypotheses}

To provide answer to the relevant questions highlighted above, the following hypotheses were formulated.

i. Automated Teller Machine usage does not significantly influence the service delivery of Money Deposit Financial Institutions in Nigeria.

ii. Use of Point-of-Sales terminal has not significantly enhanced service delivery in Nigeria's' Money Deposit Financial Institutions.

\section{Literature Review \\ Conceptual Review \\ The Concept of Electronic Payment System}

Over the years EPS needed to be more focus by scholars and the practitioners in banking sectors due to the fact that electronic payment system play a key role in modern transaction (Ahmi, Kabir \& Saidin 2015). Many researchers have defined electronic payment from different areas of specialisation. Dennis (2004) defined e-payment as a means of financial commitment that involve two or more parties to transact together through electronic linkage. Electronic payment system is a process or method where by a fund is transfer from one account to another account through internet facility (Peter \& Babatunde 2012). Joseph and Richard (2015) opined that electronic payment systems can be facilitate with the use of computer, internet facilities and applications. The system allows payments and bills to settled directly from bank account wiyhout writing or mailing any cheques.

\section{Types of E-Payment Systems}

Kabir, Saidin and Ahmi, (2015) they pointed out four types of e-payment that bank have developed for electronic transactions. These include e-cheques, e-cash, credit cards and e-fund transfers. Khan and Olanrewaju (2017) stated that Online credit card payment, electronic cash, electronic cheques and small payments are the major types of e-payment systems that available in the banking industries. 
Adeoti (2011) posits that these two banking instruments (ATM and POS) have been a useful weapon that is used by Nigeria banks to gain competitive advantage on electronic payment system like convenience, faster and prompt services. The potential users of e-payment system were relief from over stress and challenges encountered with the old system of banking practice in Nigeria. However, the advent of ATM and POS has change the operations of banking system in Nigeria (Jegede, 2014).

\section{Automated Teller Machine}

Automated Teller Machine (ATM) is a technology device that financial institution developed to link customer account with. It gives customers access to their personal account and transaction can easily be made without the need of any intermediaring or to visit the bank hall (Oladejo,2016). Bank customer can be identifying with a customized plastic ATM card containing a chip which carries a unique information with specific serial numbers and security code on the card (Oladejo, 2016). Ayo and Ukpere (2010) posits that the banking instrument used for electronic payment system in Nigeria is ATM which is the most popularly used by many customers in facilitating their transactions. The ATM can be located in different places like bank premises, hotels, Airports and any other places used for commercial purposes.

\section{Point of Sale (POS) Terminal}

It's an electronic payment solution, a device that allows customers to make instantaneous payment from his or her account to other bank accounts using cards, when making purchases or transaction (Oladejo 2016). With the POS, the merchant receives payment for goods/services purchased rather than the traditional method of accepting cash (Adeoti \& Oshotimehin, 2012). It is available in shops, supermarket, hotels and restaurants, clubs, airlines travel agencies, ticket sales outlets etc. It helps to eliminate issues associated with cash handling and movement. Merchants can have Inter Switch, Visa Debit or Master Card.

\section{Money Deposit Banks}

Money Deposit Banks are also known as Commercial banks in Nigeria, they are financial institutions that provide services such as accepting deposits, giving business loan and auto loans, mortgage leading, and basic investment product like savings accounts and certificates of activities deposit (Uzonwanne 2015). According to mainstream theory, they act as financial intermediaries to channels savers money to industries and individuals who seek funding for their acts.

\section{Benefits of Electronic Payment System}

Taddesse and Kidan (2005) posits numerous benefits that both individuals and publics can derive from the use of electronic payment to facilitate their transaction when payment is made from their account to other beneficiaries' accounts. The benefits could be a convenient and safety, it also eliminates greater convenience and provide adequate security on their transactions. The e-payment transaction has tremendously help bank customers to make their transaction easily without visiting the bank hall and avoiding them to move around with huge amount of money (Appiah \& Agyemang, 2007). Robinson (2000) pointed out numerous advantages which customers can be derived from the use of e-payment system. It reduces corruption, portability and convenience, it's also efficient and effective, improve the quality of financial reports, transparency and accountability, prevents forgery and illegal copying of e-cash, it promote good governance and it also eliminate stress particularly in writing of cheques and equally reduces the risk of stolen cheques in the event of forged signature.

\section{Risk Associated with Electronic Payment System}

Kaur and Pathak (2015) posit that the effectiveness of electronic payments system allows transfer cash to be made between two parties accounts (the seller and the buyer) instantaneously. Appiah and Agyemang (2007) assert that this can be achieved due to heavy reliance on internet. The implication of this according Lamarco (2018) is usage of internet associated to the risk of fraud, risk of tax avoidance, risk of payment conflict and risk of urge buying.

\section{Conceptual models of EPS on service delivery}

Figure 1- Electronic payment systems (EPS) and Service Delivery (SD)

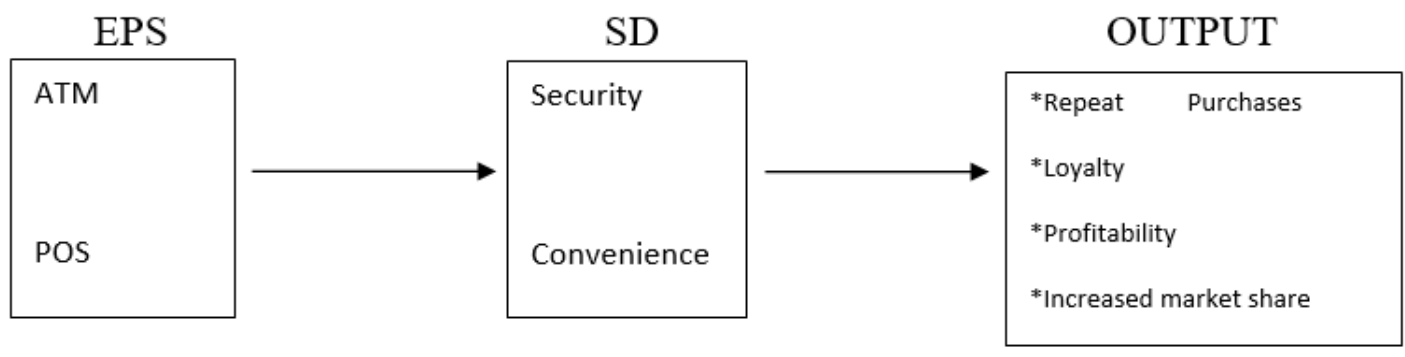

Source: Adapted from Alaka, N.S (2016) 


\section{Service Delivery}

The service delivery in the world has been improved as a result of introducing modern technology of cashless policy. This has made banking services easy for bank customers and they are the life blood of every company, without them most companies will fail to exist, therefore the need to improve service delivery is a must (Omari, 2012). Cox (1992) posits that the ATM and POS can handle cash routine enquires such as cash withdrawal, funds transfer from one account to the other, account statement request, account activity enquires and others. In advanced economy, bank customers can use their VISA and MasterCard branded ATM cards to transact banking services. Lovelock (1996) stated that the electronic payment system customized service offering reduces waiting time for customer, serves as an alternative channels for service delivery and provide vital information needed by customers in the shortest possible time. Many organizations embark on improving customer satisfaction by getting the latest machines to improve their organization performance. They believe that acquisition of latest technology will improve operating practices and the quality and quantity of their goods and services (Dauda \& Akingbade, 2011).

\section{Security}

Zlatko (2016) opined that electronic payment requires adequate security that will protect the transaction made by customers through the available banking instrument like POS and ATM or any other advance technology use for e-payment. Koponen (2016) suggested that there are two major protocol in which banks can ensure adequate security on electronic commerce transaction. These protocols are Security Socket Layer (SSL) and Security Electronic Transfer (SET). The SSL are usually used in e-commerce transactions protocol and it works by encoding the entire session amongst computers so that it enable to provide a safer communication over the internet. While the SET protocol works by preventing the prospective users entire credit card number from traveling across the internet instead allows pieces of it to flow through web communication.

\section{Convenience}

The providers of e-payment instruments have embraced the relationship marketing, to cultivate a long term relationship so that, their customers can move along the 'ladder of customer relationship' (Adewoye, 2013). In order to attain customer loyalty, long-term viability and profitability, financial institutions are placing increasing emphasis on the customer satisfaction. The service delivery occurs at customer's moment of value especially when the customers want service, where they want it, how they want it, and in a manner that is guaranteed to the customers for transactions (Adewoye, 2013).

\section{Output}

Customer dissatisfaction has a great psychological impact and a great longevity compare to good experiences as it as been estimated that two out of three times as customers will tell others of a bad experience than relate a good one. Therefore, there is a multiplier effect of bad service delivery (Singh 2013).

\section{Theoretical Framework}

The theory central to this study is diffusion innovation theory (DIT).The general idea of diffusion of innovation theory is how, why and at what new ideas and technology spread through culture. According to Roger (1995) cited in Jegede (2016) said, diffusion is the process by which an innovation is communicated through certain channels over time among members of social system. He further explained the process as one which is dictated by uncertainty reduction behavior among potential adopters during the introduction of technological innovations. Roger (1995) further explained that four variables collectively influence diffusion process: innovation, time, nature of social system and how information about the innovation is communicated. The diffusion of innovation theory (DIT) predicts how, why and to what extent bankers and bank customers in Nigeria are ready to use and accept the new policy and what relative advantage and usefulness can be derived from the new cashless policy.

\section{Empirical Review}

Numerous empirical studies have been conducted regarding to electronic payment system around the world. Ojokuku and Sajuyigbe (2012) in their study used data from 35 respondents randomly selected from 5 branches of First Bank Ltd. Their findings revealed that adoption of electronic payment system has helped banking sector in Nigeria to improve better service delivery and has boosted customer relationship and customers' satisfaction.

Idowu, Alu and Adagunogo (2002) carried out a research to investigate the effects of information technology on the growth of banking industry in Nigeria. The result from the analysis of questionnaire administered on customers of five major banks in Nigeria showed that information technology (IT) has contributed immensely to the growth of banking industry in Nigeria. According to Dauda \& Aking bade (2011) technology in most organization provided the required forces through various forms by which goods and services were produced. Singh (2013) posited that superior service delivery and satisfaction derived from services enhance the customer experience and result in improvements in loyalty, retention and subsequently business performance. The studies of Rust and Zahorik (1993) concluded that, organization with a better service delivery in terms of quality product and customer satisfaction usually lead to profitability and market share. Buzzel and Gale (1997) were in opinion that high quality service delivery and customer satisfaction 
often result in more repeat-purchases and market share improvement. Customer satisfaction leads to customer loyalty and this leads to profitability (Hallowell, 1996).

Farouk, Hassan and Mamman (2013) studied electronic banking products and performance of Nigeria deposit money banks. The study used secondary data of six (6) banks between 2006-2011, and their results shown that e-banking product (such as ATM) has strongly and significantly impacted on the performance of Nigeria banks.

\section{Research Methods}

\section{Research Design}

This study adopted Survey research design. The purpose of applying this research design method is aimed at getting fair representation of the entire population of Money deposit Banks in Lagos, Nigeria. This study covers nineteen (19) Nigeria Money Deposit banks. The research work was carried out in Lagos State because the state represented one of the most urbanized states in Nigeria where electronic payment systems are mostly used. Lagos is Nigeria financial, commercial and industrial nerve centers, where most of the commercial banks headquarter were located. Four (4) commercial banks were purposively selected based on their wide coverage and supposed large number of customers. The four (4) commercial banks that was chosen for this study are First Bank Nigeria plc, GTBank plc, United Bank of Africa (UBA) plc and Zenith Bank plc,

\section{Instrumentation}

The questionnaires administered were used to gather primary data. The research instrument was structured into three sections. The first section of the questionnaire contains general questions relating to the respondents' bio-data information. The second segment is for the staff of banks while the last section is for the customers. The questionnaire was designed in such a way that alternatives were provided for the respondents to choose from and options were expected to expressed. The research instrument was structured in five (5) Likert scale measurement of 5 represent strongly agreed (SA), 4 - agreed (A), 3 undecided (U), 2 - disagreed (D), and 1 - strongly disagreed (SD).

\section{Sampling technique and Sample size}

A total number of One hundred and twenty (120) copies of research instrument (questionnaires) were distributed to the staff and customers of the sampling frame. The participants comprise of the bank's staff and bank customers; they were selected through convenient sampling techniques. Thirty (30) copies of the research instruments were administered to each sample units of selected banks branches (GTBank plc, First Bank plc, Zenith Bank plc \& UBA plc, within Ojo local government Area. i.e. 10 was administered to bank staff and 20 to customers). Of the number of the instrument administered 108 representing $90 \%$ were retrieved and used for data analysis.

\section{Validity and Reliability of the Research Instrument}

Content validity was adopted in this study. Cronbach Alpha was adopted to determine the reliability of the research instrument (questionnaire). The result of coefficient Alphas is presented below

Tables 1: Result of reliability test using Cronbach's Alpha

\begin{tabular}{|c|l|c|c|}
\hline S/N & \multicolumn{1}{|c|}{ Variable } & No. of Items & Coefficient Alpha \\
\hline $\mathbf{1}$ & ATM usage & $\mathbf{1 2}$ & $\mathbf{0 . 7 1 3}$ \\
\hline $\mathbf{2}$ & POS terminal usage & $\mathbf{1 2}$ & $\mathbf{0 . 7 4 8}$ \\
\hline
\end{tabular}

Sources: Researcher's computation using SPSS, 2018

The test of reliability measures the internal consistency of the measurement scales of the items of each of the variables for primary data analysis. In the table 1 above shown the result of the Cronbach's Alpha of the two variables. The figures indicate the result of coefficients of the cronbach's Alpha of the variables; ATM usage and POS terminal usage are 0.713 and 0.748 respectively. Thus, since each of the coefficients lies between 0.7 and 1.00, this is an indicator of consistency that the responses measure the same characteristics of the same construct (ATM usage and POS terminal usage). Therefore, there is consistency in the measurement scales given by responses. This implies that $71.3 \%$, and $74.8 \%$ of variance in these scores of the variables respectively is reliable. The remaining percent out $100 \%$ represents error variance.

\section{Method of Data Analysis}

The analysis involved analytical approach. The analytical approach involves the test of the hypotheses by employing regression analysis. Based on the objectives and hypotheses of this study, regression model was employed for the analytical tool of the study. Regression model is a type of regression model in which the regress and (dependent variable) is qualitative in nature, whereas the explanatory variables are either qualitative, quantitative or mixture (Gujarati and Dawn, 2009). In this study, the dependent variable is the service delivery with two categories (service delivery to customer and service 
delivery by a staff member). The service delivery is assigned to the two perspectives i.e staff and customers. ' 1 ' is assigned to customer's point of view while ' 0 ' is assigned to staff member point of view. A qualitative variable such as the aforementioned variable is also called a dummy variable, since it has two categories being assigned the values 1 and 0 . A qualitative regressand with two categories is called a binary or dichotomous variable. Thus, the response variable (service delivery) in this study is a binary response variable.

However, qualitative response regression model that was adopted in this study is the binary choice model or binary response regression model since the dependent variable (service delivery) is a qualitative variable of two categories which are customers and staff member being assigned the values 1 and 0 .

The objective of employing a qualitative response regression model (binary choice model precisely) is to find the conditional probability of service delivery (dependent variable) from the two categories point of view (customers and staff) given the independent variables; Automated Teller Machine Usage $(A T M U)$ and Point-of-Sales Terminal Usage (POSTU) both as E-payment system. Thus, qualitative response regression models are often called probability models (Gujarati and Dawn, 2009).

There are four major approaches of developing and estimating a linear probability model for a binary response variable, among all this study employed the Logit Model for the data analysis.

Model Specification Using LOGIT Model

Implicitly, the functional influence of service delivery on E-payment (Automated Teller Machine Usage and Point-of-Sales Terminal Usage) system is expressed as follows:

$S D=f(A T M U, P O S T U)$

Where:

$S D=$ Service delivery

$S D= \begin{cases}1, & \text { if it is from a customer }{ }^{\prime} \text { s point of view } \\ 0, & \text { if it is from a staff member } \text { meint of }^{\prime} \text { view }\end{cases}$

$A T M U=$ Automated Teller Machine Usage

POSTU $=$ Point-of-Sales Terminal Usage

\section{Data Analysis and Results}

\section{Estimation of the results}

The LOGIT model specified in equation (8) above is given below:

Dependent Variable: SD

Method; ML- Binary Logist (Newton-Raphson / Marquardt steps)

Sample: 108

Included Observations: 108

Table 2: Result of the estimated logit model

Dependent Variable: SD

Method: ML - Binary Logit (Newton-Raphson / Marquardt steps)

Sample: 1108

Included observations: 108

\begin{tabular}{lrlrr}
\hline \hline \multicolumn{1}{c}{ Variable } & Coefficient & Std. Error & z-Statistic & Prob. \\
\hline \hline \multicolumn{1}{c}{ ATMU } & 0.849590 & 0.427432 & 1.987661 & 0.0091 \\
POSTU & 0.779320 & 0.384987 & 2.024276 & 0.0003 \\
C & 0.907068 & 0.426422 & 2.127160 & 0.0001 \\
\hline \hline McFadden R-squared & 0.035326 & Mean dependent var & 0.703704 \\
S.D. dependent var & 0.458752 & S.E. of regression & 0.454429 \\
Akaike info criterion & 1.228008 & Sum squared resid & 21.68311 \\
Schwarz criterion & 1.302512 & Log likelihood & -63.31243 \\
Hannan-Quinn criter. & 1.258217 & Deviance & 126.6249 \\
Restr. deviance & 131.2618 & Restr. log likelihood & -65.63089 \\
LR statistic & 84.63916 & Avg. log likelihood & -0.586226 \\
Prob(LR statistic) & 0.028425 & & 108 \\
\hline \hline Obs with Dep=0 & 32 & Total obs & \\
Obs with Dep=1 & 76 & & \\
\hline \hline
\end{tabular}

Source: Researcher's computation using E-views 


\section{Interpretation of Signs and Magnitudes of the coefficients}

(a) The regression coefficient of $A T M U$ " $\alpha_{1}$ "

Sign and Magnitude: In the table 2 above, the partial slope coefficient of $\boldsymbol{A T M U}$ (Automated Teller Machine Usage) with respect to $\boldsymbol{L}$ (logit or log of the odds ratio) is $\mathbf{0 . 8 4 9 6}$. With all other variable held constant, the $\boldsymbol{A T M U}$ coefficient of $\mathbf{0 . 8 4 9 6}$ implies that if $\boldsymbol{A T M U}$ increases by a unit of the responses, the estimated logit (the log of the odds in favour of customers' point of view) goes up by $\mathbf{0 . 8 4 9 6}$ (this is equivalent to 2.3387 in terms of the odds), suggesting a positive relationship between the $\boldsymbol{L}$ and $\boldsymbol{A T M U}$. More meaningfully, taking the antilog of $\mathbf{0 . 8 4 9 6}$ gives $\mathbf{2 . 3 3 8 7}$. This implies for every 1 (one) staff member in respect of service delivery there are about 3 (three) times customers with the view that Automated Teller Machine Usage has positive impact on service delivery.

\section{Test of Significance: $\quad H_{o}: \alpha_{1}=0$ and $H_{1}: \alpha_{1} \neq 0$}

In the table 2 above, the p-value of the z-statistic of the partial regression coefficient of $\boldsymbol{A T M U}$ is 0.0091 which is less than 5\%. Thus, the null hypothesis is rejected. This implies that $\boldsymbol{A T M U}$ is statistically significant to individually influence $\boldsymbol{L}$ (logit). In other words Automated Teller Machine Usage has a positively significant influence on service delivery.

\section{(b) The regression coefficient of POSTU " $\alpha_{2}{ }^{n}$}

Sign and Magnitude: In the table 2 above, the partial slope coefficient of $\boldsymbol{P O S U}$ (Point-of-Sales Terminal Usage) with respect to $\boldsymbol{L}$ (logit or log of the odds ratio) is $\mathbf{0 . 7 7 9 3}$. With all other variable held constant, the POSTU coefficient of 0.7793 implies that if POSTU increases by a unit of the responses, the estimated logit (the log of the odds in favour of customers' point of view) goes up by 0.7793 (this is equivalent to $\mathbf{2 . 1 7 8 0}$ in terms of the odds), suggesting a positive relationship between the $\boldsymbol{L}$ and POSTU. More meaningfully, taking the antilog of $\mathbf{0 . 7 7 9 3}$ gives $\mathbf{2 . 1 7 8 0}$. This implies for every 1 (one) staff member in respect of service delivery there are about 3 (three) times customers with the view that Point-of-Sales Terminal Usage has positive impact on service delivery.

$$
\text { Test of Significance: } \quad H_{0}: \alpha_{2}=0 \text { and } H_{1}: \alpha_{2} \neq 0
$$

In the table 2 above, the p-value of the z-statistic of the partial regression coefficient of POSTU is 0.0003 which is less than 5\%. Thus, the null hypothesis is rejected. This implies that POSTU is statistically significant to individually influence $\boldsymbol{L}$ (logit). In other words, Point-of-Sales Terminal Usage has a positively significant impact on service delivery.

\section{Measure of Goodness of fit}

In table 2, the McFadden $\boldsymbol{R}^{2}(0.035)$ is quite low. Thus, another comparatively simple measure of Goodness employed is the Count $\boldsymbol{R}^{2}$. This is calculated as follows:

$$
\text { Count } \boldsymbol{R}^{2}=\frac{\text { Number of correct predictors }}{\text { Total number of observations }}
$$

Since the regressand in the model is a binary response, if the predicted probability is greater than 0.5 , it is classified as 1 , but if it is less than 0.5 , it is classified as 0 . As presented in table ... appendix ..., the number of correct predictions is $\mathbf{7 6}$ out of total number of $\mathbf{1 0 8}$ observations. Therefore, the Count $R^{2}$ is computed as follows:

$$
\begin{aligned}
\text { Count } \boldsymbol{R}^{2} & =\frac{76}{108} \\
\text { Count } \boldsymbol{R}^{2} & =0.7037
\end{aligned}
$$

The coefficient of the measure of the goodness of fit of 0.7037 using Count $\boldsymbol{R}^{\mathbf{2}}$ means that $\mathbf{7 0 . 3 7 \%}$ of the variations in dependent variable (service delivery) is explain by or due to the inflence of independent variables Automated Teller Machine Usage $(A T M U)$ and Point-of-Sales terminal Usage.

\section{Global test of Significance of the Estimated Logit Regression Model}

This test is carried out to examine if all the explanatory variables are jointly or collectively have significant on influence the dependent variable (service delivery from the point of view of customers and staff members) using likelihood ratio (LR) statistic.

$$
\begin{aligned}
& H_{o}: \alpha_{1}=\alpha_{2}=0 \\
& H_{o}: \text { Not all } \alpha^{\prime} \text { s are simultaneously equal to zero }
\end{aligned}
$$

In the table 2 above, the LR-statistic is 84.6392 and its p-value is 0.0284 (less than 5\%). Thus, the null hypothesis is rejected. This implies that the independent variables Automated Teller Machine Usage $(A T M U)$ and Point-of-Sales terminal Usage are jointly significant to influence the service delivery. 


\section{Discussion of findings}

The result of hypothesis one revealed that Automated teller machine adoption affected service delivery significantly. This collaborates the work of Farouk et al (2013) who noted that the use of electronic Banking via ATM has strongly and significantly impacted in the performance of Nigeria Banks.

And the second hypothesis which stipulated that Point of Sale terminal usage significantly improved service delivery of Money Deposit Bank in Nigeria is accepted. This is in consistence with the study of Ojokuku and Sajuyigbe (2012) who revealed that the introduction of electronic payment system in the Nigeria banking sector has helped tremendously in improving the productivity of bank personnel leading to efficiency and effectiveness in service delivery.

\section{Conclusion}

The paper examined electronic payment systems and service delivery of selected Money Deposit Banks in the Lagos metropolis. Electronic payment systems refer to the mode of payment which does not include physical cash or cheques. Specifically, the paper investigated the use of Automated Teller Machines and Point-of-Sale terminals usage and their influence on the service delivery of Money Deposit Banks in Lagos, Nigeria. The results revealed that both Automated Teller Machine and Point Of Sales Terminal have significant influence on service delivery of Money Deposit Banks in Nigeria. The uses of ATM and POS have shown tremendous growth, but a lot still have to be done to increase their usage because most of the transactions are cash based.

\section{Recommendations}

For sustainability of e-payment system in the Nigeria Nigerian Money Deposit Banks, the following recommendations are to be considered:

- Spreading of automated teller machines across the towns and cities should be made possible by banks to enhance more customers service delivery.

- In order to increase patronage on EPS (ATM and POS), the Money Deposit Banks should intensify their education to sensitize the prospective users of the advantages and benefits of those instruments as a means of improving service delivery.

\section{References}

Abdullahi, B.O., Sultan, N, Khalid., Z, Nazish.B. Wajid. A \& Khan.K (2011). Customer perception towards online banking services: Empirical Evidence from Pakistan. Journal of Internet Banking and Commerce, 16 (2), 58-63.

Abubakar, A. (2014). The effective of electronic banking on growth of deposit money banks in Nigeria. EuropeanJjournal of Business and Management, 6 (33).79-89

Abubakar, A. Shagari, J. N., \& Olusegun, K.L (2015). The relationship between electronic banking and liquidity of deposit money banks in Nigeria. International Journal of Economics, Commerce and Management, 3 (9), 830 - 847.

Adeoti, O. \& Osotimehin. K (2012). Adoption of point of sale terminal in Nigeria. Assessment of consumers' level of satisfaction. Research Journal of Finance and Accounting, 3(1), 1-5.

Adeoti, J. A. (2012). Automated teller machine (ATM) frauds in Nigeria. The way out. Journal of Social Sciences, 27(1), 53-58.

Adesina, A. A. \& Ayo, C.K (2010). An empirical investigation of the level of users' acceptance of e-banking in Nigeria. Journal of Internet Banking and Commerce,15 (1),105-145

Adewoye, J.O.(2013). Impact of mobile banking on service delivery in the Nigeria commercial banks. International Review of Management and Business Research.2(2),333-344.

Agboola, A. A. (2006) "Electronic payment systems and Tele-banking services in Nigeria". Journal of Internet Banking and commerce,11(3),1-7

Alaka, N.S (2016). Strategic management of information technology and organizational performance in selected Nigeria commercial Bank. Unpublished Ph.D. thesis. Lagos State University.

Appiah, A. \& Agyemang. F (2007). Electronic retail payment systems. User acceptability and payment problems in Ghana. Blekinge institute of technology.56-66

Asika, N. (2008). Research methodology in the behavioural sciences. Lagos, Longman Nigeria Plc. Ayo, C.K. \& Ukpere, W.I. (2010). Design of a secure unified e-payment system in Nigeria. A case $\quad$ study. African Journal of Business Management, 4 (9), 1753-1760.

Baddedley, M. (2004). Using e-cash in the new economy/an economy Analysis of micro payment systems. Journal of Electronic Research, 5(7). 239-253.

Briggs, A \& Brooks, O. (2011). Electronic payment systems development in a developing country. The role of institutional arrangements. The Electronic Journal on Information System n Developing Countries, 49(3), 1-16.

Burham, K. \& Olarenwaju, R. (2017).A survey on e-payment systems: Elements, adoption, architecture, challenges and security concepts. Indian Journal of Science and Technology, 10(20), 1-19.

Buzzel, R.D \& Gale, B, T.(1997). The PIMS Principles: linking strategy to performance. Free press. New York

Chibueze, A.Z; Maxwell, O.O \& Osondu, N.M (2013). Electronic banking and bank performance in Nigeria. West African Journal of Industrial and Academic Research, 6 (1),1-7.

Dauda, Y.A \& Akingbade, W. A (2011) Technological change and employee performance in selected manufacturing industry in lagos state of Nigeria. Australian Journal of Business and Management Research.1 (5),32-43.

Delali, K. (2010). The challenge of implementing electronic payment system: The case of Ghana's E-Zwich payment system MBA Thesis. Dennis, A. (2004). Electronic payment system. User central perspective and interaction design. Netherland: Technique.

Easterby-smith, M., Thorpe, R., \& Jackson, P.R. (2008). Management research. (3rdedn). London: Sage

Farouk, M.A, Hassan, S.U \& Mamman. A. (2013). Electronic banking products and performance of Nigeria listed Deposit Money Banks. American Journal of Computer Technology and Application, 1 (10) 138-148.

Gujarati D. N. \& Dawn C. P. (2009). Basic econometrics. The McGraw-Hill Companies, Inc.

Hallowell, R. (1996). The relationships of customer satisfaction, customer loyalty and profitability. International journal of Service Industry Management. 7(4),27-42. 
Jegede,C.A (2014). Effects of automated teller machine on the performance of Nigeria banks. Science and Education Publishing, $2(1), 40-46$. Idowu, P.A, Alu, A.O. \& Adagunodo, E.R. (2002). The effect of information technology on the growth of the banking Industry in Nigeria. The Electronic Journal of Information Systems in Developing Countries, 10 (2) 1-8.

Idris, A. A, Olumoko, T.A \& Ajemunigbohun, S.S (2013). The role of information technology in customer service delivery and firm performance: Evidence of Nigeria's Insurance Industry. International Journal of Marketing Studies, 5 (4), 59 - 71

Ilugbemi, A.O \& Tijani, J.O (2015). Electronic payment channels in the Nigeria banking sector and its impacts on national development. Asian Economic and Financial Review, 5(3), 521 - 531.

Jean, B.H (2018). The Role of Electronic payment system on the financial performance of financial institutions in Rwanda. Global Journal of Management and Business Research Finance, 18 (1), 52 - 60.

Jegede, C. A (2016). Cashless policy and economic development in Nigeria: A Quantitative Approach, Ogun Journal of Accounting Banking \& Finance. 145-159.

Joseph, O. \& Richard, I. (2015). Electronic payment system in Nigeria: its Economic benefits and challenges. Journal of Education and Practice, 6 (16), 56-62.

Kabir, M.A., Saidin, S.Z. \& Ahmi, A. (2015). Adoption of e-payment system. Conference paper. International conference on e-commerce, Proceedings of International Conference on E-commerce, 20 - 22 October, Kuching, Malaysia.

Kaur, K\& Pathak. A. (2015).e-payment system on e-commerce in Indian karamjeet kaur. International Journal of Engineering Research and Application, 5(2) 79-87.

Koponen, A. (2006). E-commerce,electronic payments.Helsinki university of technology. Telecommunications software and multimedia laboratory.

Kelvin, O (2012). Mobile money for financial inclusion. Journal of micro finance Africa Nett, Lagos. 4:14. National bureau of statistic. Annual statistical report. 13:11.

Kothari, C.R., \& Garg, G. (2016). Research methodology: Methods and techniques. (3 ${ }^{\text {rd }}$ edn). New Delhi: New Age International (P) Limited. Lovelock, C.(2001). Service Marketing, People, Technology, Strategy, Prentice Hall, New Jersey.

Manocharan. B (2007), Indian e-payment system and performance. Banker, 7 (3), 66-69.

Mercy, 0. \& Tennyson. O. (2014). Payment system and it sustainable development in the Nigeria Economy. European journal of Business and Management, Vol. 6 (8), 48 -56.

Nwankwo, S. I. \& Ajemunigbohun, S. S. (2016). Empirical examination of the implementation of electronic payment systems in service delivery of insurance companies in Nigeria. Journal of Economics and Management, 24(2), 64 - 76.

Ojokuku, R.M. \& Sajuyigbe, AS. (2012). The impact of electronic banking on human resources performance in the Nigeria banking industry. International Journal of Economics Development Research and Investment, 3(2), 61-69.

Okeke, T. C, Nwatu, B. C \& Ezeh, G, A (2017). Predicting consumer adoption of point of purchase e-payment system using extended technology acceptance modeling. British Journal of Marketing Stusies, 5(8). 1-11.

Okoro, A. S (2014). Impact of electronic banking instruments on the intermediate efficiency of the Nigeria Economy. International Journal of Accounting Research,1(6),1 - 9.

Oladejo, M.O. (2016). E-payment adoption and customers' service delivery in Nigeria deposit money banks. International Journals of Application or Innovation in Engineering and Management, 5 (3), 130 -138.

Peter, M. $O$ \& Babatunde, P. J. (2012). E-payment: prospects and challenges in the Nigeria public sector. International Journal of Modern Engineering Research, 5(2). 3104-3106.

Reichheld. F.(1996). The Loyalty Effect. Harvard business school press. Boston.

Rogers, E. M (2003). Diffusion of ilnnovations . New York; Free Press.

Rogers, E. M (1995). Diffusion of Innovations. $4^{\text {th }}$ ed. New York: The Free Press

Roy, S. \& Sinha. I (2014). Determinants of customers' acceptance of Electronic payment systems in Indian Banking sector. International Journal of Scientific and Engineering Research, 5(1), 177 - 187.

Rust, R. T \& Zahorik, A. J (1993). Customer satisfaction,customer retention and market share. Journal of retailing, 69(2),193-215.

Sekaran, U \& Bougie. R (2016) Research methods for business. A skill-building approach. (7th edn). USA: John Wiley \& Sons Limited.

Sing, $S$. (2013). The impact of service of service delivery quality on customer satisfaction in India banks .International Journal Financial Services and Management. 6(1), 60-78.

Shoewu, $O$ and Edeko, F.O. (2011). Outgoing call quality evaluation of GSM network services in Epe, Lagos State. American Journal of Scientific and Industrial Research, 2 (3), 409 - 417.

Soludo, C. (2007), Macro economics, monetary and financial sector development in Nigeria (CBN). Retrieved from: www.cenbank.org.

Sumanjeet, $S$ (2009). Emergence of payment system in the age of electronic commerce: The state of art. Asia Pacific Journal of Finance and Banking Research, 3 (3), 18-40.

Summanject, S. (2008). Securing payment systems in the age of commerce. International Journal of Management Research and Technology, 2 (1), $19-32$

Taddesse, W \& Kidan, T (2005). E-payment: Challenges \& Opportunities in Ethiopia. United. International Journal of Scientific and Research Publications. 6(8) 1-8

Teoh, W. M, Chong, S. C, Lin. B \& Chua, J. W (2013). Factor affecting customers' perception of electronic payment: An empirical. Internet Research, 23(4), 465-485.

Uzonwanne, M. C.(2015). Deposit money banks and financing of small and medium scale enterprises in Nigeria. Journal of Economics and Sustainable Development. 6(8),185-195.

Zlatko, B.(2016). The future of the mobile payment as electronic payment system. European Journal of Business and Management, 8(8), 127132 